\title{
Abnormal Plasma Glucose and Insulin Responses in Heterozygous Lean $(o b /+)$ Mice
}

\author{
P. R. Flatt ${ }^{1}$ and C. J. Bailey ${ }^{2}$ \\ ${ }^{1}$ Department of Biochemistry, University of Surrey, Guildford, Surrey, and ${ }^{2}$ Department of Biological Sciences, \\ University of Aston in Birmingham, Birmingham, England
}

Summary. To investigate the effect of the $o b$ gene in the heterozygous condition, plasma glucose and insulin responses of adult heterozygous lean $(o b /+)$ mice were compared with mice of the homozygous lean $(+/+)$ and homozygous obese $(o b / o b)$ genotypes. The $o b /+$ mice consumed $24 \%$ more food than $+1+$ mice although body weights were similar. Plasma glucose and insulin concentrations were respectively $16 \%$ and $176 \%$ higher in $o b /+$ mice than $+1+$ mice in the freely fed state, and $44 \%$ and $88 \%$ higher during glucose tolerance tests. In 24 hour fasted $o b l+$ mice, plasma glucose concentrations were $23 \%$ higher than $+/+$ mice but plasma insulin concentrations were not significantly different. Arginine produced a greater insulin response $(172 \%)$ and a greater fall in glycaemia $(200 \%)$ in $o b /$ + mice. A significant difference in the hypoglycaemic effect of insulin in $a b /+$ and $+1+$ mice was not observed. These results demonstrate an effect of the $a b$ gene on glucose homeostasis in heterozygous lean $(o b /+)$ mice. The abnormalities were qualitatively similar but considerably less severe than those in $o b / o b$ mice, suggesting that $a b /+$ mice might prove useful to study factors predisposing to inappropriate hyperglycaemia.

Key words: Expression of $o b$ gene, glucose tolerance, insulin secretion, insulin sensitivity, $o b /+$ mice, obese hyperglycaemic syndrome.

The obese hyperglycaemic (ob/ob) syndrome in mice is characterized by numerous metabolic abnormalities, the most prominent of which include obesity, hyperglycaemia, hyperinsulinaemia and insulin resistance $[6,18]$. The inheritance of the syndrome as an autosomal recessive trait [21] implies that a single nucleic acid in the genetic code has been altered, resulting in the synthesis of a defective peptide. The one-gene-one peptide concept has assisted the elucidation of a number of genetically transmitted diseases associated with mild abnormalities in the heterozygous condition [17].

Several studies have provided evidence for the existence of a gene-dosage effect in heterozygous lean $(a b /+)$ mice. Decreased glucose oxidation in adipose tissue [27], decreased oxygen consumption [23] and increases in epididymal fat cell size [22], percentage carcass fat content $[4,8]$, pituitary ACTH content [9], insulin-releasing pituitary factor $[4,5]$ and circulating concentrations of corticosterone [19] and insulin [8] have been implicated in this respect. This study examines plasma glucose and insulin responses in adult lean heterozygous $(o b /+)$ mice. Possible defects in the heterozygote are particularly interesting with regard to the aetiology of the $a b / o b$ syndrome.

\section{Materials and Methods}

\section{Animals}

Homozygous obese (ob/ob), heterozygous lean $(o b /+)$ and homozygous lean $(+/+)$ mice from the colony maintained at the University of Aston in Birmingham were used in a present study. Male mice of each genotype were examined at 20 weeks of age. Throughout this period, the animals were housed in an air-conditioned room at $22 \pm 2^{\circ} \mathrm{C}$ with a regular lighting schedule of $9.5 \mathrm{~h}$ light $(0800-1730 \mathrm{~h})$ and $14.5 \mathrm{~h}$ dark. A standard pellet diet (Mouse breeding diet, Heygate \& Sons Ltd, Northampton) and tap water were supplied ad libitum. Food was withheld $24 \mathrm{~h}$ prior to certain experiments as indicated below.

A selective breeding programme was used to provide established $o b /+$ and $+1+$ lean mice. Heterozygous breeding pairs were originally identified by mating unclassified lean $(? /+)$ mice 
Table 1. Body weight and food consumption in $+/+, a b /+$ and $o b / o b$ mice

\begin{tabular}{lll}
\hline Genotype & $\begin{array}{l}\text { Body weight } \\
(\mathrm{g})\end{array}$ & $\begin{array}{l}\text { Food consumption } \\
(\mathrm{g} / 24 \mathrm{~h} / \text { animal) }\end{array}$ \\
\hline$+1+$ & $38.8 \pm 1.3$ & $7.5 \pm 0.5$ \\
$o b /+$ & $40.7 \pm 1.3$ & $9.3 \pm 0.5$ \\
$a b / o b$ & $89.7 \pm 5.2$ & $9.0 \pm 0.6$ \\
$\begin{array}{ll}\text { Statistical comparisons } \\
+/+v s o b /+\end{array}$ & $\mathrm{NS}$ \\
$+/+v s o b / o b$ & $\mathrm{p}<0.001$ & $\mathrm{p}<0.05$ \\
$o b /+v s o b / a b$ & $\mathrm{p}<0.001$ & $\mathrm{NS}$
\end{tabular}

Values are presented as the mean \pm SEM for groups of six 20 weeks old male mice

NS represents no significant difference

from litters containing obese individuals. The presence of obese animals among the progeny indicated that both parents were heterozygous. The mice judged $o b /+$ from these matings were not used for experimental work, serving only for breeding purposes. Subsequently, $a b /+$ mice were identified by the presence of obese progeny after backcrossing to an established $o b /+$ mouse. Mice were deemed $+1+$ when no obese progeny were obtained after 6 backcrosses to proven $a b /+$ mice. Lean mice originating from different $+1+$ parents were paired, enabling a true breeding line of $+1+$ mice to be established within the colony.

It has been emphasized that both the severity and developmental pattern of the diabetic syndrome in obese hyperglycaemic mice result from the interaction of the mutant gene with modifiers of the background genome $[7,18]$. For this reason, the genetic background of the colony is defined in detail below. Original C57BL/6I heterozygous $(a b /+)$ breeding pairs from the Jackson Laboratory, Bar Harbor, U.S. A. were obtained in 1957 by Professor D. S. Falconer of the Institute of Animal Genetics at the University of Edinburgh, U.K. Heterozygous mice were outcrossed at Edinburgh to two non-inbred local strains: to $\mathrm{JH}$, selected for higher litter size [12] and maintained as a closed non-inbred stock for 5 generations; and to CRL, selected for faster growth rate [11] and maintained for ten generations as a closed non-inbred stock. Heterozygous mice from this stock were outcrossed to two further non-inbred local strains in 1966 , and $o b /+$ breeding pairs from the resultant stock were obtained by the University of Aston in Birmingham in the same year. These mice were used to establish a closed non-inbred colony which has now exceeded thirty generations. The severity of the diabetes in the Aston stock is intermediate between that of $\mathrm{C} 57 \mathrm{BL} / 6 \mathrm{~J}$ and C57BL/Ks.J $o b / o b$ mice $[3,18]$.

\section{Chemicals}

Reagents of analytical grade and distilled water were used throughout. The chemicals and their sources were as follows: $\mathrm{L}$ arginine hydrochloride and activated charcoal from Sigma (London) Chemical Company Limited, Poole, U. K.; monocomponent porcine insulin (Actrapid) and crystalline mouse insulin from Novo Industria $\mathrm{A} / \mathrm{S}$, Copenhagen, Denmark; bovine serum albumin (fraction V) from Miles Laboratories Ltd., Slough, U. K.; sterile horse serum (no. 5) from Wellcome Reagents Limited, Beckenham, U. K.; dextran T-70 from Pharmacea (Great Britain) Limited, London, U. K.; ${ }^{125}$ Y-bovine insulin from The Radiochemical Centre, Amersham, U. K.; D-glucose and other reagents from British Drug Houses Limited, Poole, U. K.

\section{Experimental Procedures}

Experiments were started at $0900 \mathrm{~h}$. Body weight and food consumption were measured over six consecutive periods of $24 \mathrm{~h}$ [2]. The following test substances were administered by intraperitoneal injection: glucose, $2 \mathrm{~g} / \mathrm{kg}$ body weight $(400 \mathrm{~g} / 1)$ in water; arginine hydrochloride, $1.5 \mathrm{~g} / \mathrm{kg}(300 \mathrm{~g} / \mathrm{l})$ in $0.154 \mathrm{mmol} / \mathrm{l}$ sodium chloride; and monocomponent porcine insulin, $0.25 \mathrm{U} / \mathrm{kg}(50 \mathrm{U} / 1)$ in $0.154 \mu \mathrm{mol} / 1$ sodium chloride. In view of the insensitivity of $a b / o b$ mice to exogenous insulin, these mice were also treated with $100 \mathrm{U}$ insulin $/ \mathrm{kg}$ in $0.154 \mathrm{~mol} / 1$ sodium chloride. The glucose tolerance tests were performed on fed mice. Arginine and insulin were administered to $24 \mathrm{~h}$ fasted mice. Food was witheld during all tests. Blood samples $(50 \mu \mathrm{l})$ were obtained from the cut tip of the tail of conscious mice [16] immediately before and after injection of the test substance at the times indicated in the Tables. The blood was collected into chilled polyethylene microfuge tubes ( $250 \mu$ capacity) that had been prewashed with a solution of heparin $(500 \mathrm{U} / \mathrm{ml})$. Plasma was separated by centrifugation for $15 \mathrm{~s}$ at approximately $9000 \mathrm{~g}$ using a microfuge (type B, Beckman Riic Limited, High Wycombe, U. K.) and stored at $-20^{\circ} \mathrm{C}$. All plasma samples were processed at the same time to avoid between-assay variability.

\section{Analytical Procedures}

Plasma glucose was determined in $10 \mu \mathrm{l}$ samples by an automated glucose oxidase procedure [26] using a Beckman glucose analyzer (Beckman Riic Limited, High Wycombe, U. K.). Insulin was measured in 10-20 $\mu$ l plasma by radioimmunoassay [1] using horse serum and dextran-coated charcoal for separation of free from bound antigen. Twice crystallized mouse insulin (biological potency $22.4 \mathrm{IU} / \mathrm{mg}$ was used as the standard. Charcoal-treated insulin-free plasma was used to minimize nonspecific interference, and the guinea pig anti-porcine insulin antiserum was selected for its high affinity for mouse insulin. These reagents were prepared by modifications of the methods described elsewhere $[1,20]$. Radioimmunoassay data analysis was performed by an I. C. L. $1904 S$ computer according to a programme [15] developed using the precepts of Rodbard [25]. Assay sensitivity as defined by Ekins and colleagues $[1,10]$ was $0.5 \mathrm{pg} / \mathrm{ml}$, corresponding to a $10 \%$ fall in bound counts on the addition of $9.2 \mathrm{pg}$ mouse insulin. The assay discriminated changes of $6 \mathrm{pg} / \mathrm{ml}$ at concentrations less than $1.25 \mathrm{ng} / \mathrm{ml} ; 100 \mathrm{pg} / \mathrm{ml}$ between $1.25-5 \mathrm{ng} / \mathrm{ml}$; and $300 \mathrm{pg} / \mathrm{ml}$ at higher concentrations. Plasma samples containing $0.1-24.5 \mathrm{ng} / \mathrm{ml}$ insulin gave a within assay coefficient of variation of $1.3-4.2 \%$.

\section{Statistics}

Groups of data were compared using Student's t-test. Differences were considered to be significant if $p<0.05$. The results are presented as mean \pm SEM where appropriate.

\section{Results}

\section{Body Weight and Food Consumption}

The $a b /+$ mice consumed more food than $+1+$ mice, but their body weights were not significantly different (Table 1). The $o b / o b$ mice showed gross obesity. At this age, the food intake of $o b / o b$ mice was not significantly different from either $o b /+$ or $+/+$ mice. 
Table 2. Plasma glucose and insulin concentrations after the administration of glucose $(2 \mathrm{~g} / \mathrm{kg})$ to fed $+/+, o b /+$ and $o b / o b$ mice

\begin{tabular}{|c|c|c|c|c|c|c|}
\hline \multirow[t]{2}{*}{ Genotype } & \multicolumn{3}{|c|}{ Plasma glucose $(\mathrm{mmol} / \mathrm{l})$} & \multicolumn{3}{|c|}{ Plasma insulin (ng/ml) } \\
\hline & zero & $30 \mathrm{~min}$ & $60 \mathrm{~min}$ & zero & $30 \mathrm{~min}$ & $60 \mathrm{~min}$ \\
\hline $\begin{array}{l}+/+ \\
o b /+ \\
o b / o b\end{array}$ & $\begin{aligned} 7.7 & \pm 0.2 \\
8.9 & \pm 0.3 \\
11.9 & \pm 0.7\end{aligned}$ & $\begin{array}{l}10.4 \pm 0.6^{\mathrm{b}} \\
14.8 \pm 1.1^{\mathrm{c}} \\
34.8 \pm 1.7^{\mathrm{c}}\end{array}$ & $\begin{array}{c}9.0 \pm 0.7 \\
13.2 \pm 0.6^{\mathrm{c}} \\
28.5 \pm 2.3^{\mathrm{c}}\end{array}$ & $\begin{aligned} 1.23 & \pm 0.22 \\
3.40 & \pm 0.69 \\
28.8 & \pm 3.5\end{aligned}$ & $\begin{array}{l}2.41 \pm 0.31^{\mathrm{a}} \\
4.20 \pm 0.72 \\
23.6 \pm 4.3\end{array}$ & $\begin{array}{r}1.50 \pm 0.73 \\
3.16 \pm 0.41 \\
27.4 \pm 3.1\end{array}$ \\
\hline $\begin{array}{l}\text { Statistical compa } \\
+/+v s o b /+ \\
+/+v s o b / a b \\
o b /+v s o b / o b\end{array}$ & $\begin{array}{l}p<0.01 \\
p<0.001 \\
p<0.01\end{array}$ & $\begin{array}{l}p<0.01 \\
p<0.001 \\
p<0.001\end{array}$ & $\begin{array}{l}p<0.01 \\
p<0.001 \\
p<0.001\end{array}$ & $\begin{array}{l}p<0.02 \\
p<0.001 \\
p<0.001\end{array}$ & $\begin{array}{l}p<0.05 \\
p<0.001 \\
p<0.01\end{array}$ & $\begin{array}{l}\text { NS } \\
p<0.001 \\
p<0.001\end{array}$ \\
\hline
\end{tabular}

Values are presented as the mean \pm SEM for groups of six 20 weeks old male mice

${ }^{\mathrm{a}} \mathrm{p}<0.02 ;{ }^{\mathrm{b}} \mathrm{p}<0.01 ;{ }^{\mathrm{c}} \mathrm{p}<0.001$ compared with value at zero time. NS represents no significant difference

Table 3. Plasma glucose and insulin concentrations after the administration of arginine $(1.5 \mathrm{~g} / \mathrm{kg})$ to 24 hour fasted $+/+, o b /+$ and $o b / o b$ mice

\begin{tabular}{|c|c|c|c|c|c|c|}
\hline \multirow[t]{2}{*}{ Genotype } & \multicolumn{3}{|c|}{ Plasma glucose $(\mathrm{mmol} / \mathrm{l})$} & \multicolumn{3}{|c|}{ Plasma insulin (ng/ml) } \\
\hline & zero & $15 \min$ & $30 \mathrm{~min}$ & zero & $15 \mathrm{~min}$ & $30 \mathrm{~min}$ \\
\hline $\begin{array}{l}+/+ \\
o b /+ \\
o b / o b\end{array}$ & $\begin{array}{l}4.5 \pm 0.2 \\
5.3 \pm 0.1 \\
8.8 \pm 0.5\end{array}$ & $\begin{array}{c}4.1 \pm 0.2 \\
3.5 \pm 0.2^{\mathrm{c}} \\
10.2 \pm 1.2\end{array}$ & $\begin{array}{l}3.8 \pm 0.2^{a} \\
3.3 \pm 0.2^{c} \\
5.6 \pm 0.7^{b}\end{array}$ & $\begin{array}{l}0.28 \pm 0.07 \\
0.38 \pm 0.04 \\
4.3 \pm 0.4\end{array}$ & $\begin{aligned} 0.88 & \pm 0.12^{\mathrm{b}} \\
2.61 \pm 0.33^{\mathrm{c}} & \pm .3^{\mathrm{c}}\end{aligned}$ & $\begin{array}{r}0.26 \pm 0.06 \\
0.29 \pm 0.11 \\
51.2 \pm 2.3^{\mathrm{c}}\end{array}$ \\
\hline $\begin{array}{l}\text { Statistical compa } \\
+/+v s o b /+ \\
+/+v s o b / o b \\
o b /+v s o b / o b\end{array}$ & $\begin{array}{l}p<0.01 \\
p<0.001 \\
p<0.001\end{array}$ & $\begin{array}{l}\text { NS } \\
p<0.001 \\
p<0.001\end{array}$ & $\begin{array}{l}\text { NS } \\
p<0.05 \\
p<0.01\end{array}$ & $\begin{array}{l}\text { NS } \\
p<0.001 \\
p<0.001\end{array}$ & $\begin{array}{l}p<0.001 \\
p<0.001 \\
p<0.001\end{array}$ & $\begin{array}{l}\text { NS } \\
p<0.001 \\
p<0.001\end{array}$ \\
\hline
\end{tabular}

Values are presented as mean \pm SEM for groups of six 20 weeks old male mice

${ }^{\mathrm{a}} \mathrm{p}<0.05 ;{ }^{\mathrm{b}} \mathrm{p}<0.01 ;{ }^{\mathrm{c}} \mathrm{p}<0.001$ compared with value at zero time. NS represents no significant difference

\section{Basal Plasma Glucose and Insulin Concentrations}

In the freely fed state, plasma glucose and insulin concentrations were higher in $o b /+$ than $+/+$ mice (Table 2). The basal plasma glucose concentration of $o b /+$ mice was also higher than $+/+$ mice in the 24 hour fasted state (Table 3 ) but the plasma insulin concentration was not significantly different. The $o b / o b$ mice exhibited moderate hyperglycaemia and marked hyperinsulinaemia in the freely fed state. These mice also displayed higher glucose and insulin concentrations in the 24 hour fasted state (Table 3). The plasma glucose and insulin concentrations of all three groups of mice were significantly reduced following a 24 hour fast.

\section{Response to Glucose}

Glucose tolerance was impaired in freely fed $o b /+$ mice compared with $+/+$ mice, even though the plasma insulin concentrations of $a b /+$ mice exceeded those of $+1+$ mice (Table 2 ). Nevertheless, a significant increase in the plasma insulin concentration was not observed following administration of glucose to $o b /+$ mice. The $o b / o b$ mice showed a marked impairment of glucose tolerance, with no plasma insulin response to glucose.

\section{Response to Arginine}

Administration of arginine to 24 hour fasted mice produced a greater plasma insulin response and a larger fall of glycaemia in $o b /+$ than $+/+$ mice (Table 3). The $o b / o b$ mice displayed a markedly enhanced plasma insulin response to arginine without a significant change in the plasma glucose concentration.

\section{Response to Insulin}

The hypoglycaemic effect of $0.25 \mathrm{U} / \mathrm{kg}$ insulin was not significantly different in 24 hour fasted $o b /+$ and $+1+$ mice (Table 4$)$. The rate of plasma glucose disappearance $(\% / \mathrm{min})$ was $1.16 \pm 0.20 \mathrm{in} o b /+$ mice and $1.28 \pm 0.12$ in $+/+$ mice. The $o b / o b$ mice displayed impaired insulin sensitivity as indicated by the lack of effect of insulin $0.25 \mathrm{U} / \mathrm{kg}$ on the plasma glucose concentration. Administration of insulin 
Table 4. Plasma glucose concentrations after the administration of insulin to 24 hour fasted $+/+, o b /+$ and $o b / o b$ mice

\begin{tabular}{|c|c|c|c|c|}
\hline \multirow[t]{2}{*}{ Genotype } & \multirow[t]{2}{*}{ Dose of insulin } & \multicolumn{3}{|c|}{ Plasma glucose $(\mathrm{mmol} / \mathrm{l})$} \\
\hline & & zero & $15 \mathrm{~min}$ & $30 \mathrm{~min}$ \\
\hline$+/+$ & $0.25 \mathrm{U} / \mathrm{kg}$ & $4.3 \pm 0.2$ & $3.9 \pm 0.2^{\mathrm{a}}$ & $3.0 \pm 0.1^{\mathrm{c}}$ \\
\hline$a b /+$ & $0.25 \mathrm{U} / \mathrm{kg}$ & $5.5 \pm 0.1$ & $4.8 \pm 0.2^{\mathrm{a}}$ & $3.6 \pm 0.2^{c}$ \\
\hline$a b / o b$ & $0.25 \mathrm{U} / \mathrm{kg}$ & $8.2 \pm 0.5$ & $9.1 \pm 0.4$ & $7.5 \pm 0.5$ \\
\hline$a b / o b$ & $100 \quad \mathrm{U} / \mathrm{kg}$ & $8.6 \pm 0.3$ & $6.0 \pm 0.5^{\mathrm{b}}$ & $3.9 \pm 0.3^{c}$ \\
\hline \multicolumn{5}{|c|}{ Statistical comparisons } \\
\hline$+1+v s o b /+$ & $0.25 \mathrm{U} / \mathrm{kg}$ & $\mathrm{p}<0.001$ & $\mathrm{p}<0.01$ & $\mathrm{p}<0.05$ \\
\hline$+1+v s o b / a b$ & $0.25 \mathrm{U} / \mathrm{kg}$ & $\mathrm{p}<0.001$ & $\mathrm{p}<0.001$ & $\mathrm{p}<0.001$ \\
\hline$a b /+v s o b / a b$ & $0.25 \mathrm{U} / \mathrm{kg}$ & $\mathrm{p}<0.001$ & $\mathrm{p}<0.001$ & $\mathrm{p}<0.001$ \\
\hline
\end{tabular}

Values are presented as mean \pm SEM for groups of six 20 weeks old male mice

${ }^{\mathrm{a}} \mathrm{p}<0.05 ;{ }^{\mathrm{b}} \mathrm{p}<0.01 ;{ }^{\mathrm{c}} \mathrm{p}<0.001$ compared with value at zero time. NS represents no significant difference. The rate of glucose disappearance $(\% / \mathrm{min})$ was $1.28 \pm 0.12$ for $+/+, 1.16 \pm 0.20$ for $o b /+$, and $1.25 \pm 0.30$ for $o b / o b$ mice

$100 \mathrm{U} / \mathrm{kg}$ produced a significant hypoglycaemic response in 24 hour fasted $a b / o b$ mice. The rate of glucose disappearance in these mice was $1.25 \pm$ $0.30 \% / \mathrm{min}$.

\section{Discussion}

Most studies on the obese hyperglycaemic syndrome have not discriminated between $o b /+$ and $+/+$ lean control mice. Furthermore, reports specifically concerned with a gene-dosage effect in $o b /+$ mice have often relied on the frequency distribution of a particular characteristic, assuming a Mendelian ratio of $1: 2: 1$ for $o b / a b, a b /+$ and $+/+$ siblings from known heterozygote matings $[8,9,22,23]$. Thus of the abnormalities previously documented in $a b /+$ mice, only the studies on adipose tissue glucose oxidation [27], circulating corticosterone [19], insulinreleasing pituitary factor $[4,5]$ and percentage carcass fat [4], have been determined by comparison of established $o b /+$ and $+/+$ genotypes.

Using adult mice of proven genotype, the present study revealed that $o b /+$ mice consumed more food and exhibited higher plasma concentrations of glucose and insulin, impaired glucose tolerance, a blunted plasma insulin response to glucose and an exaggerated plasma insulin response to arginine. These observations demonstrate a small but significant effect of the $o b$ gene in $a b /+$ mice, emphasizing that future studies on $o b / o b$ mice should employ homozygous lean $(+/+)$ mice as the appropriate controls. However, the partial expressivity of the $a b$ gene does provide a useful opportunity to study the basic expression of the mutation without the encumbering multiple metabolic abnormalities manifest in $o b / o b$ mice.
Although the primary defect leading to the development of the $a b / o b$ syndrome is unknown [6, 18 ], it is not unreasonable to assume that the $o b$ gene results in the production of a defective enzyme or structural protein. A current hypothesis which would account for the pleiotropic nature of this defect is the synthesis of an abnormal thyroid-dependent $\mathrm{Na}^{+}$$\mathrm{K}^{+}$-ATPase which interferes with transmembrane ionic gradients in several tissues [6]. The manifestation of mild metabolic abnormalities in the heterozygote indicates the existence of a gene-dosage effect in which the + gene predominates over the $a b$ gene. Thus it seems probable that the + gene normally provides sufficient competent enzyme or structural protein to accommodate most of the metabolic demands made by $o b /+$ mice.

The existence of hyperinsulinaemia in fed but not fasted $o b /+$ mice suggests that factors related to hyperphagia may be responsible for the raised plasma insulin concentrations. Indeed, the ingestion and intestinal absorption of nutrients may provide important stimuli for the elevation of plasma insulin concentrations in $o b / o b$ mice [24]. For example, the developmental pattern of hyperinsulinaemia in $o b / o b$ mice parallels that of hyperphagia [3], and intraperitoneal glucose fails to induce a positive plasma insulin response in the fed state whereas oral glucose evokes a marked increase in the plasma insulin concentrations [13]. In $o b /+$ mice, a reduced plasma insulin response to intraperitoneal glucose was observed, indicating impaired B-cell responsiveness to this sugar. This interpretation is consistent with the lack of basal hyperinsulinaemia in the presence of raised plasma glucose concentrations in fasted $o b /+$ mice.

The impaired plasma insulin response to glucose does not represent a general secretory defect since 
arginine provoked an exaggerated insulin response in $o b /+$ and $o b / o b$ mice. In contrast to $o b / o b$ mice, the $o b /+$ mice displayed a marked fall in the plasma glucose concentration after arginine. The maintenance of hyperglycaemia after arginine stimulation of insulin secretion in $o b / o b$ mice may be attributed to the gross insulin insensitivity in this genotype. Accordingly, the hypoglycaemic effect of arginine in $o b /+$ mice suggests that insulin sensitivity is not appreciably impaired. Indeed within the limits of the insulin hypoglycaemia test, it was not possible to demonstrate a significant difference between the insulin sensitivity of $o b /+$ and $+/+$ mice. This implicates additional factors in the production of hyperglycaemia in $o b /+$ mice. Since preliminary studies have shown that circulating glucagon contributes significantly to the hyperglycaemia of $a b / o b$ mice [14], inappropriate hyperglucagonaemia might be one of the factors responsible for the elevated plasma glucose concentrations of $o b /+$ mice.

In conclusion, the present study has demonstrated impaired glucose homeostasis in heterozygous lean $(o b /+)$ mice. In view of the abnormal plasma glucose and insulin responses, $o b /+$ mice may provide a useful model for studies on the interaction of genetic and environmental factors predisposing to inappropriate hyperglycaemia.

Acknowledgements. The authors are grateful to Dr. D. L. Coleman of the Jackson Laboratory, Bar Harbor, U.S. A. and Professor D.S. Falconer of the Institute of Animal Genetics, Edinburgh, U.K. for their cooperation. We also acknowledge the excellent animal care provided by Melvin Gamble, Paul Behan and Brian Burford.

\section{References}

1. Albano JDM, Ekins RP, Maritz G, Turner RC (1972) A sensitive precise radioimmunoassay of serum insulin relying on charcoal separation of bound and free hormone moieties. Acta Endocrinol (Kbh) 70: 487-509

2. Bailey CJ, Atkins TW, Connor MJ, Manley CG, Matty AJ (1975) Diurnal variations of food consumption, plasma glucose and plasma insulin concentrations in lean and obese hyperglycaemic mice. Horm Res 6: 380-386

3. Bailey CJ, Flatt PR, Atkins TW (in press) Influence of genetic background and age on the expression of the obese hyperglycaemic syndrome in Aston $a b / a b$ mice. Int J Obesity

4. Beloff-Chain A, Bogdanovic S, Cawthorne MA (1979) Acute regulation of insulin release by the pituitary gland in relation to hyperinsulinaemia and obesity. J Endocrinol 81: 271-279

5. Beloff-Chain A, Hawthorn J, Green D (1975) Influence of the pituitary gland from the homozygote $(+/+)$ and heterozygote $(o b / t)$ lean mouse on insulin secretion in vitro. FEBS Lett 55: $72-74$

6. Bray GA, York DA (1979) Hypothalamic and genetic obesity in experimental animals: An autonomic and endocrine hypothesis. Physiol Rev 59: 719-809

7. Coleman DL, Hummel KP (1973) The influence of genetic background on the expression of the obese $(o b)$ gene in the mouse. Diabetologia 9: 287-293
8. Dubuc PU (1976) The development of obesity, hyperinsulinaemia and hyperglycaemia in $o b / o b$ mice. Metabolism 25: $1567-1574$

9. Edwardson JA, Hough CAM (1975) The pituitary-adrenal system of the genetically obese $(a b / o b)$ mouse. J Endocrinol 65: 99-107

10. Ekins RP, Newman GB, O'Riordan JLH (1968) Theoretical aspects of saturation and radioimmunoassay. In: Hales RL, Grosswitz FA, Murphy BEP (eds) Radioisotopes in medicine, in vitro studies. US Atomic Energy Commission, Oak Ridge, p 59-100

11. Falconer DS (1960) Selection of mice for growth on high and low planes of nutrition. Genet Res 1: 91-113

12. Falconer DS (1960) The genetics of litter size in mice. J Cell Comp Physiol 56 [Suppl 1]: 153-167

13. Flatt PR, Bailey CJ (in press) Importance of the enteroinsular axis for the insulin secretory response to glucose in obese hyperglycaemic $(o b / o b)$ mice. Biochem Soc Trans

14. Flatt PR, Swanston-Flatt SK, Bailey CJ (1979) Glucagon antiserum: A tool to investigate the role of circulating glucagon in

- obese hyperglycaemic ( $a b / o b)$ mice. Biochem Soc Trans 7: 911-913

15. Flatt PR, Thornburn CC, Bailey CJ (1979) A computer approach to the analysis of radioimmunoassay data. J Endocrinol 80: 50P-51P

16. Grice HC (1964) Methods for obtaining blood and for intravenous injections in laboratory animals. Lab Animal Care 14: 483-493

17. Harris H (1966) Human biochemical genetics. Cambridge University Press, London New York, p 1-310

18. Herberg L, Coleman DL (1977) Laboratory animals exhibiting obesity and diabetes syndromes. Metabolism 26: 59-99

19. Herberg L, Kley HK (1975) Adrenal function and the effect of a high-fat diet on $\mathrm{C} 57 \mathrm{BL} / 6 \mathrm{~J}$ and $\mathrm{C} 57 \mathrm{BL} / 6 \mathrm{~J}-o b / o b$ mice. Horm Metab Res 7: 410-415

20. Hurn BAL, Landon J (1971) Antisera for radioimmunoassay. In: Kirkham KE, Hunter WM (eds) Methods in radioimmunoassay. Churchill Livingstone, Edinburgh London, p 121-142

21. Ingalls AM, Dickie MM, Snell GD (1950) Obesity, a new mutation in the house mouse. J Hered 41: 317-318

22. Joosten HFP, van der Kroon PHW (1974) Enlargement of epididymal adipocytes in relation to hyperinsulinaemia in obese hyperglycaemic mice $(o b / o b)$. Metabolism 23: 59-66

23. Kaplan ML, Leveille GA (1974) Core temperature, $\mathrm{O}_{2}$ consumption and early detection of $o b / a b$ genotype in mice. Am J Physiol 227: 912-915

24. Polak JM, Pearse AGE, Grimelius L, Marks V (1975) Gastrointestinal apudosis in obese hyperglycaemic mice. Virchows Arch [Pathol Anat] 19: 135-150

25. Rodbard D (1974) Statistical quality control and routine data processing for radioimmunoassays and immunoradiometric assays. Clin Chem 20: 1255-1270

26. Stevens JF (1971) Determination of glucose by automatic analyser. Clin Chem 32: 199-201

27. Yen TTT, Lowry L, Steinmetz J (1968) Obese locus in Mus musculus: A gene dosage effect. Biochem Biophys Res Commun 33: 883-887

Received: November 7, 1980,

and in revised form: December 11, 1980

Dr. P. R. Flatt

Department of Biochemistry

University of Surrey

Guildford, Surrey GU2 5XH

England 